\title{
INTERNATIONALIZATION IN ENTERPRISES FROM LUBELSKIE REGION (POLAND) - DOES THE DISTANCE MATTER?
}

\author{
Beata ŻUKOWSKA* \\ Ada DOMAŃSKA ${ }^{* *}$ \\ Robert ZAJKOWSKI ${ }^{* *}$
}

\begin{abstract}
Internationalization is a complex phenomenon that can be described as process in which firms increase their involvement in foreign markets. It can be treated as a chance for small and medium enterprises to face the challenges which are the effects of globalization, such as global competition or growing needs of potential customers. Lubelskie region (eastern Poland) is one of the poorest, and as our research show - has rather small potential for internationalization. Nevertheless, we believe that if the actual barriers are indicated, more proper conclusions and recommendations for regional entrepreneurs and policy makers will be stated. In order to do that we apply the CAGE model framework and analyze the results of quantitative research which was conducted among enterprises from lubelskie region (voivodeship). As the initial results show, economic and especially political distance is the most determinative while choosing business partners.
\end{abstract}

Keywords: internationalization, barriers, enterprises, Poland

JEL Classification:

\section{Introduction}

Internationalization is a complex phenomenon that can be described as process in which firms increase their involvement in foreign markets (Johanson \& Vahlne 1977; Welch \& Luostarinen 1988 ) or it can be defined as the adaptation of firms' operations to international environments (Mejri \& Umemoto 2010). It can occur in enterprises in many forms (Cieślik, 2011). Among internationalization activities we can indicate:

1. Obtaining certificates, licence, permissions for selling on the foreign market.

* MSc, Maria Curie-Sklodowska University, Department of Banking, beata.zukowska@umcs.pl, ORCID: 0000-0002-5644-6963

** PhD, Maria Curie-Sklodowska University, Department of Banking, ada.domanska@umcs.pl, ORCID: 0000-0002-8239-4319

*** PhD, Maria Curie-Sklodowska University, Department of Banking, robert.zajkowski@umcs.pl, ORCID: 0000-0002-0021-7977

To cite this article: Żukowska, B., Domańska, A. \& Zajkowski, R. (2019). Internationalization in Enterprises from Lubelskie Region (Poland) - Does the Distance Matter?. Journal of Research in Business, 4(1), 46-54. DOI: 10.23892/JRB.2019453294 
2. Taking part in international trade - selling or buying products, employing foreign employees.

3. Capital connections and investments abroad.

4. Joint international scientific projects, international conferences, internships.

5. Licence agreements and with foreign entities.

6. Taking part in international trade fairs.

7. Protection of intellectual property in the international system.

In our research we stick to the first interpretation of internationalization construct in order to find out which internationalization activities and geographical destinations are the most common in lubelskie region - region situated in eastern Poland, classified as an emerging market (according to FTSE Russell, since September 2018, Polish market is defined as developed, however our research was conducted before this date). We decided to focus on this topic, as the internationalization can be treated as a chance for small and medium enterprises to face the challenges which are the effects of globalization, such as global competition or growing needs of potential customers. As the Polish authors claim, the most common form of internationalization among Polish enterprises is international trading (Gołębiowski, 2007, Hajduk, 2007, Plawgo, 2004). According to the data from Polish Central Statistical Office, in 2014, 7,8\% were importing goods, 1,3\% - services. The same database show, that in 2014 4,4\% of all Polish enterprises exported goods, and only 1\% - services (Polish Agency of Enterprise Development, 2015). Still, the least internationally active are enterprises, which employ less than 10 employees. Among enterprises which employ between 10-49, and 50-250 people, consequently $42,4 \%$ and $58,1 \%$ import, $31,1 \%$ and $46,8 \%$ export goods. This number still should be treated rather as insufficient, especially considering exporting activities.

Lubelskie region is one of the poorest, and as our research show - has rather small potential for internationalization. Nevertheless, we believe that if the actual barriers are indicated, we will be able to state more proper conclusions and recommendations for regional entrepreneurs. This research was undertaken in order to find out where entrepreneurs from lubelskie region are looking for their foreign business partners, which barriers are treated as the most important and try to explain why the internationalization level is not sufficient.

This research is a starting point for further examination of this phenomenon, so should be treated rather as a diagnosis of the current state.

\section{About the Region}

The lubelskie region is one of the poorest regions in Poland, situated in eastern part of the country. As the development indicators present (Tab 1), performance of this region are rather weak in comparison with other ones (Domańska, Żukowska, \& Zajkowski, 2018). 
Table 1: Development Indicators for Each region of Poland (Data for 2015)

\begin{tabular}{|c|c|c|c|c|c|}
\hline $\begin{array}{l}\text { Indicators } \\
\text { Regions }\end{array}$ & $\begin{array}{c}\text { GDP per capita } \\
\text { in euro (current } \\
\text { prices) }\end{array}$ & $\begin{array}{l}\text { Total length of } \\
\text { express-ways } \\
\text { and motorways } \\
\text { per } 1000 \mathrm{~km}^{2}\end{array}$ & $\begin{array}{c}\text { Investment } \\
\text { outlays per } \\
\text { capita (current } \\
\text { prices) }\end{array}$ & $\begin{array}{c}\text { Gross value } \\
\text { of fixed assets } \\
\text { in enterprises } \\
\text { per capita - } \\
\text { Poland }=100\end{array}$ & $\begin{array}{l}\text { Value of foreign } \\
\text { capital per capita } \\
\text { (Poland }=100)\end{array}$ \\
\hline POLAND & 11200 & 9,8 & 7069 & 100 & 100 \\
\hline Łódzkie & 10500 & 22,3 & 6980 & 94,5 & 39 \\
\hline Mazowieckie & 15500 & 7,2 & 10868 & 171,2 & 340 \\
\hline Małopolskie & 10100 & 11,4 & 6277 & 76,7 & 70 \\
\hline Śląskie & 11600 & 24,9 & 6445 & 117 & 71 \\
\hline Lubelskie & 7700 & 3,2 & 4837 & 53,5 & 14 \\
\hline Podkarpackie & 7900 & 6,9 & 5172 & 64,5 & 48 \\
\hline Podlaskie & 7900 & 2,3 & 5754 & 61,1 & 7 \\
\hline Świętokrzyskie & 8100 & 4,9 & 4624 & 67,4 & 40 \\
\hline Lubuskie & 9300 & 16,6 & 5762 & 94,1 & 27 \\
\hline Wielkopolskie & 12200 & 12,1 & 7291 & 105,3 & 119 \\
\hline Zachodniopomorskie & 9500 & 7 & 6383 & 82,5 & 86 \\
\hline Dolnośląskie & 12500 & 14,3 & 7800 & 118,4 & 110 \\
\hline Opolskie & 9000 & 9,4 & 8062 & 87,5 & 40 \\
\hline Kujawsko-pomorskie & 9000 & 11,1 & 6692 & 76,2 & 25 \\
\hline Pomorskie & 10700 & 7,5 & 7277 & 93,2 & 65 \\
\hline Warmińsko-mazurskie & 7900 & 5,8 & 5587 & 57,1 & 19 \\
\hline
\end{tabular}

Source: Central Statistical Office of Poland, Eurostat.

This fact impacts also on the region's potential for internationalization. We indicate 18 characteristics, which are supportive for internationalization of Polish regions (Tab 2) and we compare lubelskie voivodship with others. In order to do that, we use the data from the Central Statistical Office and the Strateg Database (it collects data used in verification of specific regional and central strategies) from the year 2011 to 2015 . 
Table 2: Characteristic of Regions Used in Examining the Potential of Lubelskie Region

\begin{tabular}{|l|l|}
\hline 1 & Hard surface public roads per $100 \mathrm{~km} 2$ \\
\hline 2 & Density of expressways and motorways per $1000 \mathrm{~km} 2$ \\
\hline 3 & Total railway lines per $100 \mathrm{~km} 2$ \\
\hline 4 & Export's share of non-financial enterprises with foreign capital in GDP \\
\hline 5 & Share of net revenues from sales of new or significantly improved products of total turnover in industrial enterprises \\
\hline 6 & Share of foreign capital located in entities in the voivodship in the total value of the capital in Poland \\
\hline 7 & Investment outlays per capita (current prices) \\
\hline 8 & National scheduled bus transport lines per 1 thousand inhabitants \\
\hline 9 & GDP per capita (current prices) \\
\hline 10 & Number of Small and Medium-Size Enterprises per 10 thousands inhabitants in working age \\
\hline 11 & $\begin{array}{l}\text { Share of industrial enterprises which participated in innovation activities cluster co-operation or in other formal } \\
\text { types of co-operation in number of innovation active enterprises - entities employing 10-249 persons }\end{array}$ \\
\hline 12 & $\begin{array}{l}\text { Share of industrial enterprises which participated in innovation activities cluster co-operation in total enterprises } \\
\text { participating in innovation activities co-operation }\end{array}$ \\
\hline 13 & $\begin{array}{l}\text { Share of service enterprises which participated in innovation activities cluster co-operation in total service enterprises } \\
\text { participating in innovation activities co-operation }\end{array}$ \\
\hline 14 & $\begin{array}{l}\text { Share of enterprises which participated in innovation activities co-operation in the total number of innovation active } \\
\text { enterprises }\end{array}$ \\
\hline 15 & $\begin{array}{l}\text { Business environment institutions (financial and insurance activities, real estate activities) per } 10 \text { thous. entities of } \\
\text { the national economy }\end{array}$ \\
\hline 16 & $\begin{array}{l}\text { Number of foundations, associations and social organizations recorded in the REGON register per } 10 \text { thous. } \\
\text { Inhabitants }\end{array}$ \\
\hline 17 & Number of newly registered entities of the national economy in the REGON register per 10 thousands inhabitants \\
\hline 18 & Number of entities of the national economy recorded in the REGON register per 10 thousands inhabitants \\
\hline
\end{tabular}

Source: Central Statistical Office of Poland, Strateg Database

We applied the zero unitarization method. This normalisation method was chosen, mainly because it is simplicity leads to easy interpretation of gained results. Moreover, as Kukula (2012) states, this method fulfil three important criteria:

1. After normalisation lengths of intervals of variability for all features are the same.

2. The lower and upper limits of intervals of variability for all features are the same: $[0,1]$.

3. Features which have a zero value can be also normalised.

Formulas used in zero unitarization method, go as follows:

$$
\begin{aligned}
& z_{i j}=\frac{x_{i j}-\min _{i} x_{i j}}{\max _{i} x_{i j}-\min _{i} x_{i j}}, X_{j} \in S \\
& z_{i j}=\frac{\max _{i} x_{i j}-x_{i j}}{\max _{i} x_{i j}-\min _{i} x_{i j}}, X_{j} \in D
\end{aligned}
$$


Where: zij is the standardized value of the variable $\mathrm{Xj}$ in the object $\mathrm{Wi}$ and xij is the value of the variable $\mathrm{Xj}$ in the object Wi. The object Wi is described by the vector of diagnostic variables:

$\mathrm{X}_{\mathrm{i}}=\left[\mathrm{x}_{\mathrm{i} 1}, \mathrm{x}_{\mathrm{i} 2} \ldots \mathrm{x}_{\mathrm{in}}\right],(\mathrm{i}=1, \ldots, \mathrm{r})$

Formula 1 is used with variables which are stimulants (if they increase, the level of analysed phenomena increases) and formula 2 is used with destimulants (if they increase, the level of analysed phenomena decreases). In order to rank analysed regions, all variables need to be normalised and then summed up for each object :

$q_{i}=\sum_{j-1}^{n} z_{i j}, \quad i=(1, \ldots, r)(4)$

qi - a synthetic variable, which assess the i-th object.

The results of analysis of the data from 2011-2015 show that lubelskie region is one of the least likely to have a potential for internationalization. As the graph 1 present, only one region has been ranked a little lower. This situation is caused by many factors, still, the most significant are: low GDP per capita, small number of entities which already exist and those newly registered. However, factors connected with infrastructure (i.e. total length of express-ways and motorways per $1000 \mathrm{~km} 2$ ) are also unsatisfying.

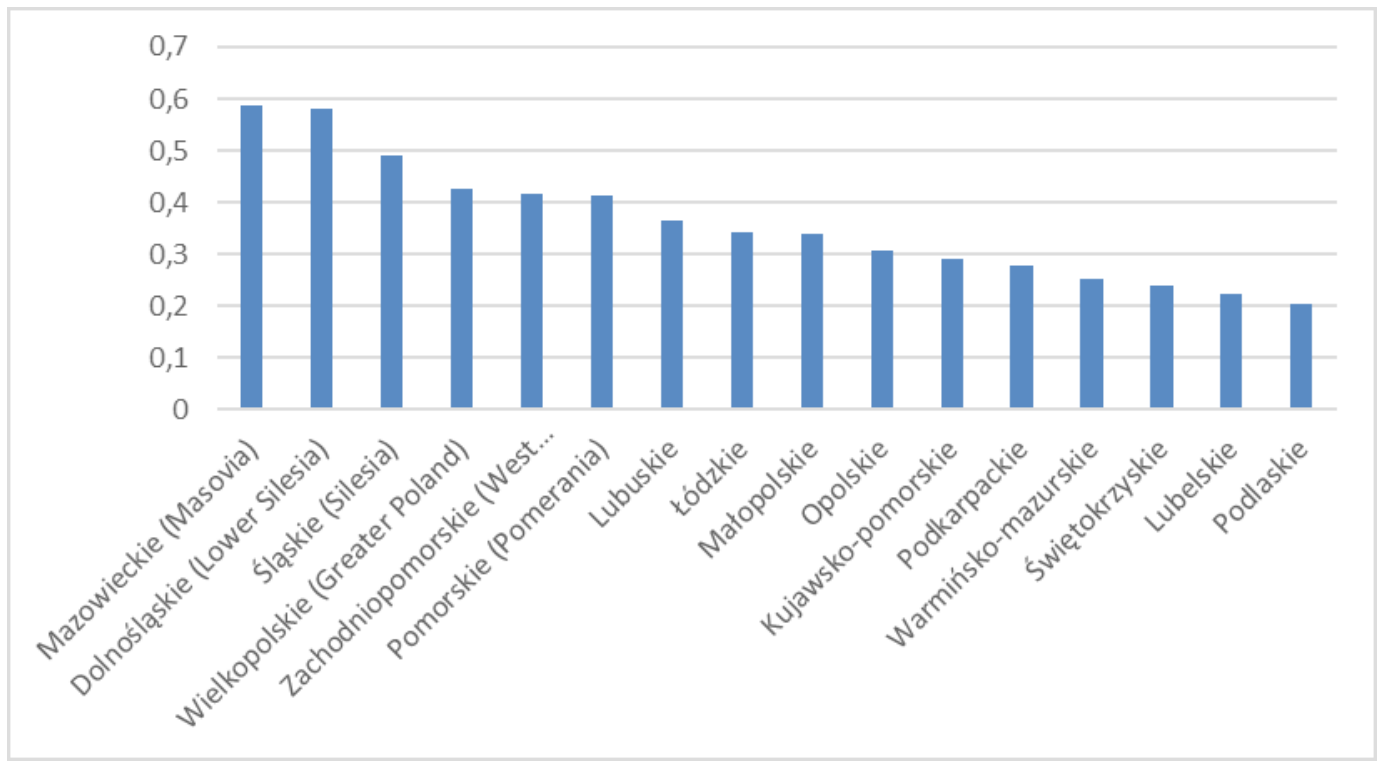

Figure 1: The Evaluation of Internationalization Potential Among Polish Regions (Based on Own Calculations) 
As the more complex research said, it is also one of the least internationalized voivodeship in Poland - in 2014 only 12,6\% of enterprises carried out international cooperation in any form (Polish Agency of Enterprise Development 2014). The Lubelskie borders Ukraine and Belarus - two post-soviet countries, outside the European Union. Despite similar history (communist regime), rather lack of language barriers (people leaving in the communist regime were forced to learn Russian in schools, so nowadays many people from post-soviet bloc can easily communicate) and common land border - factors which are supportive for bilateral cooperation (Ricart et al. 2004) - these countries are not very popular business partners for the examined region.

\section{Internationalization Barriers}

Choosing international expansion directions can be determined by many factors. According to the CAGE model (Ghemawat 2001, Hasan \& Ibrahim, 2016), four dimensions of the distance can be indicated: cultural, administrative/political, geographic and economic. Those dimensions can be diagnosed in bilateral and multilateral perspective. In the graph 1, we present which factors can determines the specific dimension of the bilateral distance (between two countries). We can assume, that they can be treated as potential obstacles, which are rather tough or even impossible for individual entity which operates in specific region (like lubelskie) to overcome, when it wants to cooperate with a business partner from a specific country.

\begin{tabular}{ll}
\hline CULTURAL \\
$\begin{array}{l}\text { Different languages } \\
\text { Different ethnicities; lack of connective ethnic or social } \\
\text { networks } \\
\begin{array}{l}\text { Different religions } \\
\text { Lack of trust }\end{array}\end{array}$ & $\begin{array}{l}\text { ADMINISTRATIVE } \\
\text { Lack of colonial ties } \\
\text { Lifferent values, norms, and dispositions } \\
\text { Lack of common currency } \\
\text { Political hostility }\end{array}$ \\
\hline GEOGRAPHICAL & \\
Physical distance & ECONOMIC \\
Lack of land border & Rich/poor differences \\
Differences in time zones & Other differences in cost or quality of natural resources, \\
Differences in climates / disease environments & financial resources, human resources, infrastructure, \\
\hline
\end{tabular}

Graph 1: The Dimensions of Distance in CAGE Model (Bilateral Perspective)

There are also the same dimensions which describes more universal obstacles for internationalization, that can be apply not only when we analyze the pair of business partners, but might be rather considered as a hamper factors, which exist in a country or specific region. These are presented on the graph 2 . 


\begin{tabular}{ll}
\hline CULTURAL & ADMINISTRATIVE \\
Traditionalism & Corruption \\
Insularity & Lack of membership in international organizations \\
& Weak institutions \\
& Nonmarket/closed-economy \\
\hline GEOGRAPHICAL & ECONOMIC \\
Weak transportation or communication links & Low per capita income \\
Geographic size & Economic size \\
\hline
\end{tabular}

Graph 2: The Dimensions of Distance in CAGE Model (Multilateral Perspective)

Cultural dimension is determined mainly by the history of the given region and is rather difficult to be changed. Similarly, the geographical dimension - it is impossible to overcome the lack of land border. However, taking into consideration the development of the transportation - physical distance becomes more important obstacle. Nevertheless, the most likely barriers to be reduce, are those categorized as administrative and economic dimension of the distance. In that case, implementation of central or regional policy which supports the given areas can be beneficial for the entities which considering the internationalization activities.

\section{Methods Used}

In May and June 2017 we conducted questionnaire-based research among enterprises operating in lubelskie region, which declared that they employ more than 10 people. The final sample reached 276 enterprises. The sample reflects the proportion of enterprises' localization in 4 subregions in lubelskie voivodeship (stratified sampling). The chi square test revealed that number of enterprises in each localisation was not significantly different from the actual structure of the population for tested region. Respondents were asked to complete a paper-based questionnaire, which included questions about their financial situation, competitiveness, internationalization and planning systems. In this research we use mainly descriptive analyses in order to find out which geographical pathways are the most popular and what kind of obstacles enterprises from lubelskie region face when they decide to internationalize their business.

\section{Results}

In our sample $27 \%$ of enterprises claim that they cooperate with foreign firms (export or import, mostly incidental), $18,11 \%$ declare at least one export partner. $17,4 \%$ of enterprises take part in international trade fairs or conferences, $8,1 \%$ realise joint projects with foreign businesses or have license contracts, only $1,1 \%$ declares having stocks in foreign companies.

We discovered that the most common direction for expansion in enterprises from lubelskie voivodeship is Germany (6,88\% of examined enterprises export their goods or services there) and 
the United Kingdom $(3,26 \%)$. Ukraine - the neighbor of lubelskie region was indicated as a business partner among 2,9\% of enterprises, Belarus as the direction of extension is even less popular - only among $1,09 \%$ of enterprises. However, entrepreneurs from lubelskie region cooperate with businesses located in emerging economies such as Czech Republic $(2,9 \%)$.

Entrepreneurs were also asked to indicate, which obstacles they find the most difficult to overcome, in order to start any internationalization activities. They has to choose and evaluate on the 5-grade scale which barrier is the most important for them. According to the CAGE model, we categorized the most common barriers taking into consideration all four dimensions: cultural, geographical, administrative and economic. Examined barriers are presented on the figure 2, and the letter after each barrier describes which dimensions it represent. Our research show that the most of indicated issues were those connected with financial/economic sphere and administration. In addition they were evaluated as the most important i.e.: meeting the needs of foreign consumers, maintain foreign market, finding honest business partners, acquiring reliable information about foreign market.

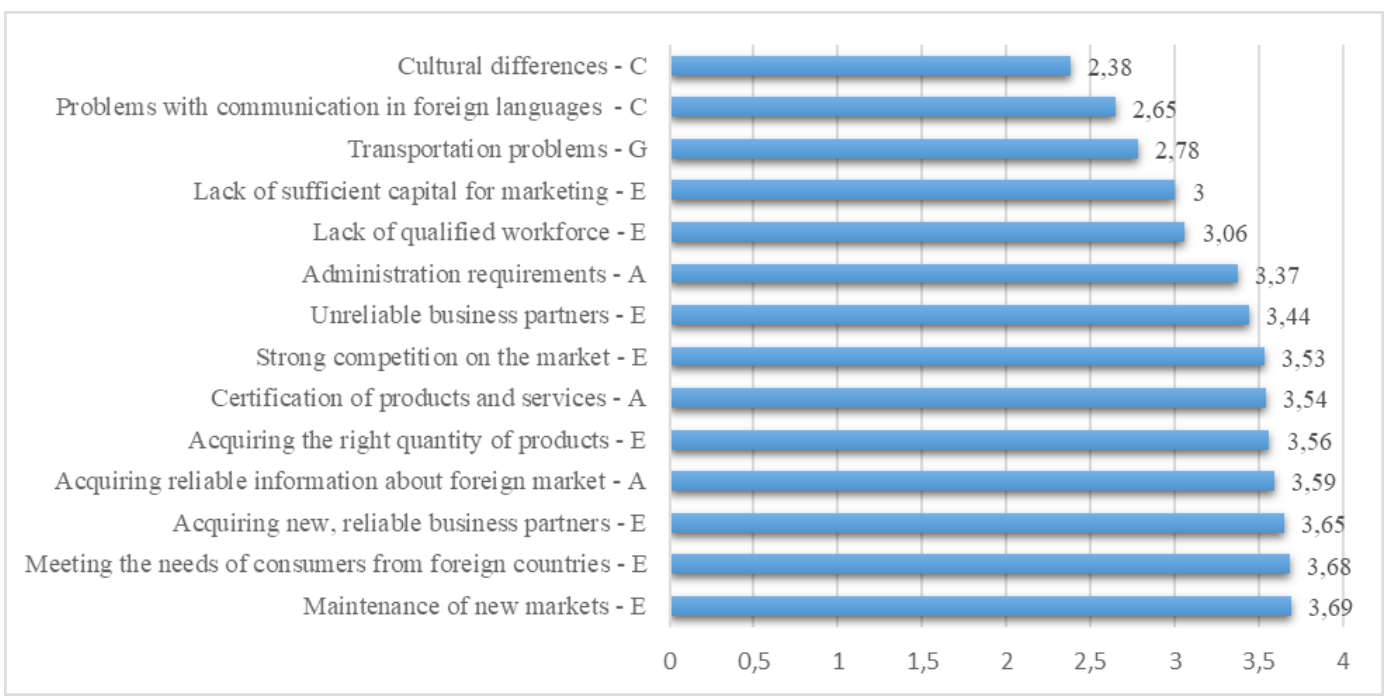

Figure 2: Evaluation of Internationalization Barriers Indicated by Enterprises from Lubelskie Region C Cultural, G - Geographical, E - Economic, A - Administrative Dimension.

\section{Conclusion}

Those findings lead to conclusions that enterprises from lubelskie region despite of very low physical distance to their neighbours (Belarus and Ukraine) are not very keen to cooperate with those countries. European integration has a significant meaning in this case, as it support expansion among member countries. Eastern countries such Ukraine or Belarus are perceived as more risky, taking into consideration their political and economy situation. Considering internationalization 
barriers that respondent enterprises indicate, we may conclude that despite cultural similarities and geographic localization, economic and especially political distance is more determinative while choosing business partners. We indicate that in lubelskie region the most important barriers are not these connected with distance or culture. More important are economic and administrative obstacles. Knowing that, in the further research these two areas will be the examined more specifically. On this stage of the research, we could state a conclusion, that policy-makers in lubelskie region should channel their efforts on alleviating economic and administrative barriers, which are the most crucial in the cooperation with its closest neighbors.

\section{References}

Cieślik J., (2011). Internacjonalizacja młodych innowacyjnych firm, Polska Agencja Rozwoju Przedsiębiorczości, Warszawa 2011.

Domańska, A., Żukowska, B., \& Zajkowski, R. (2018). Importance of Individual Characteristics of Entrepreneurs and Perception of Factors Determining the Start-Up of a Business in the Lubelskie Voivodship, Barometr Regionalny, 16(3), 101-108.

Ghemawat, Pankaj. 2001. “Distance Still Matters.” Harvard Business Review, 79(September), 137-147. http:// search.ebscohost.com/login.aspx?direct=true\&db=bth\&AN=5134712\&site=ehost-live.

Gołębiowski, T., \& Witek-Hajduk, M. (2007). Formy internacjonalizacji polskich przedsiębiorstw. Marketing $i$ Rynek, (2), 16-22.

Gołębiowski, T., \& Witek-Hajduk, M. (2007). Stopień internacjonalizacji polskich przedsiębiorstw. Marketing $i$ Rynek, (1), 15-21.

Hasan, M., \& Ibrahim, Y. (2016). Institutional Distance Factors Influencing on Firm Performance: A Hypothetical Framework from Cross-Border Mergers and Acquisitions, The Journal of Developing Areas, 50(6), 377-386.

Johanson, J., \& Vahlne, J. E. (2006). Commitment and opportunity development in the internationalization process: A note on the Uppsala internationalization process model. Management International Review, 46(2), 165-178.

Mejri, K., \& Katsuhiro U. (2010). Small - and Medium-Sized Enterprise Internationalization: Towards the Knowledge-Based Model. Journal of International Entrepreneurship 8(2): 156-67.

Plawgo B., (2004). Zachowania małych i średnich przedsiębiorstw w procesie internacjonalizacji, Orgmasz, Warszawa.

Polish Agency of Enterprise Development. (2014). Raport Końcowy. Ewaluacja Potencjału Eksportowego Przedsiębiorstw W Polsce. Warszawa.

Polish Agency of Enterprise Development. (2015), Raport o stanie sektora matych $i$ średnich przedsiębiorstw w Polsce 2016, Warszawa.

Ricart, J. E., Enright, M. J., Ghemawat, P., Hart, S. L., \& Khanna, T. (2004). New frontiers in international strategy. Journal of International Business Studies, 35(3), 175-200.

Welch, L. S., \& Luostarinen, R. (1988). Internationalization: Evolution of a concept. Journal of general management, 14(2), 34-55.

www.stat.gov.pl

www.strateg.stat.gov.pl 